\title{
Low-Density Lipoprotein Receptor-Related Protein 2
}

National Cancer Institute

\section{Source}

National Cancer Institute. Low-Density Lipoprotein Receptor-Related Protein 2. NCI

Thesaurus. Code C113302.

Low-density lipoprotein receptor-related protein 2 (4655 aa, $200 \mathrm{kDa}$ ) is encoded by the human LRP2 gene. This protein plays a role in receptor-mediated endocytosis. 